\title{
O mítico como produto turístico: o caso do lobisomem da Estância Turística de Joanópolis/SP
}

The mythical as a tourist product: the case of the werewolf of the tourist city of Joanópolis/SP

La mítica como un producto turístico: el caso del hombre lobo de la ciudad turística de Joanópolis/SP

http://dx.doi.org/10.18472/cvt.18n1.2018.1230

Leonardo Giovane Moreira Gonçalves 〈leonardo.giovane@hotmail.com > Universidade Estadual Paulista (Unesp), Rosana, SP, Brasil

Juliana Maria Vaz Pimentel 〈 jmvpimentel@outlook.com.br >

Universidade Federal da Grande Dourados (UFGD), Dourados, MS, Brasil

Fábio Luciano Violin 〈violin@rosana.unesp.br >

Universidade para o Desenvolvimento do Estado e da Região do Pantanal (Uniderp), Campo Grande, MS, Brasil

CRONOLOGIA DO PROCESSO EDITORIAL

Recebimento do artigo: 15-jan-2016

Aceite: 25 -out-2017

FORMATO PARA CITAÇÃO DESTE ARTIGO

GONÇALVES, L. G. M.; PIMENTEL, J. M. V.; VIOLIN, F. L. O mítico como produto turístico: o caso do lobisomem da Estância Turística de Joanópolis/SP. Caderno Virtual de Turismo. Rio de Janeiro, v. 18, n. 1, p. 101-115, abr. 2018.

REALIZAÇÃO

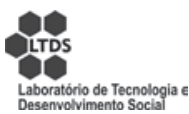

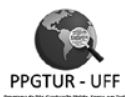

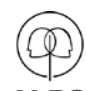

APOIO INSTITUCIONAL

EDIÇÃO

PATROCÍNIO

COPPE

UFR]

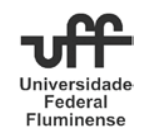

EDITORA

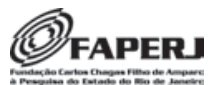




\section{RESUMO}

As rupturas de hábitos culturais, bem como a inserção dos povos na era digital, impactam de modo plausível as relações sociais. As inovações tecnológicas, a facilidade de acesso e o comodismo proporcionado pela internet implicam em uma nova reestruturação dos atrativos turísticos para que esses possuam força de estímulo. Nesse êmulo insere-se o empreendimento como atrativo turístico, sendo esse conduzido a modificar-se para atrair público e transformando-se assim no próprio atrativo. Assim, com intuito de analisar a potencialidade do atrativo enquanto um chamariz para turistas, em especial considerando o caso do mito do Lobisomem de Joanópolis/SP, o presente artigo analisou as potencialidades do local como atrativo, tendo como objeto de estudo o Botequim da Cachaça. Para isso, utilizou-se de uma pesquisa bibliográfica exploratória e uma entrevista semiestruturada com os proprietários do estabelecimento comercial, Wilson e Lurdes. Tais metodologias permitiram aferir o papel do mito como produto turístico e, sobretudo, de que modo ele pode ser utilizado para a constituição da imagem de um destino, na diversificação da oferta e na captação de demanda turística.

Palavras-chave: Lobisomem. Mito. Atrativo. Apropriação Comercial. Joanópolis.

\section{ABSTRACT}

Disruptions of cultural habits as well as the inclusion of people in the digital age, impacts plausibly in social relations. Technological innovations, ease of access and the indulgence offered by the internet, imply a further restructuring of tourist attractions so these have attractive force. Emulate this is part of the enterprise as a tourist attraction, and this led to change in order to attract public and becoming so attractive in itself. Thus, aiming to analyze the potential of the attraction as a magnet for tourists, especially considering the Werewolf Myth case Joanópolis / SP, this article analyzed the site's potential as attractive, with the object of study the Botequim da Cachaça, dealing with an exploratory literature search and a semi-structured survey of the owners of the premises, Wilson and Lurdes, which allowed assessing the myth's role as a tourism product and, especially, how it can be used for image formation of a destination, diversification of the offer and capture of tourism demand.

Keywords: Werewolf. Myth. Attractive. Commercial Ownership. Joanópolis.

\section{RESUMEN}

Escapadas de hábitos culturales, así como la inclusión de las personas en la era digital, los impactos plausiblemente en las relaciones sociales. Las innovaciones tecnológicas, facilidad de acceso y la indulgencia que ofrece internet, implica una reestructuración adicional de los lugares turísticos por lo que estos tienen fuerza de atracción. Emular esto es parte de la empresa como una atracción turística, y esto llevó a cambiar con el fin de atraer público y convertirse en tan atractivo en sí mismo. Por lo tanto, con el objetivo de analizar el potencial de la atracción como un imán para los turistas, sobre todo teniendo en cuenta el caso del hombre lobo Mito Joanópolis / SP, este artículo analiza el potencial del sitio tan atractivo, con el objeto de estudio del Botequim da Cachaça, se trata de una búsqueda bibliográfica exploratoria y una encuesta semiestructurada de los propietarios de los locales, Wilson y Lourdes, lo que permitió evaluar el papel del mito como un producto turístico y, sobre todo, la forma en que se puede utilizar para la formación de la imagen de un destino, diversificación de la oferta y en la captura de la demanda turística.

Palavras clave: Hombre lobo. Mito. Atractivo. Propiedad comercial. Joanópolis. 


\section{INTRODUÇÃO}

O avanço tecnológico forneceu às pessoas maior mobilidade e comodidade. Serviços e produtos que outrora eram oferecidos e executados nos estabelecimentos comerciais, na atualidade podem ser adquiridos sem sair de casa, um exemplo clássico são as compras de produtos pelas lojas virtuais presentes na internet.

Desse modo, além do grande número de concorrentes que cresce a cada ano, as empresas, em especial as do ramo turístico, têm como desafio driblar a comodidade promovida pela internet e vencer a inércia que impulsiona os consumidores a ficarem em suas residências, objetivando ofertar opções de deslocamento, lazer e turismo.

Assim, nessa sociedade competitiva com fatores de grande influência que interferem no macro e no microambiente empresarial, bem como diante da recessão econômica que se verifica atualmente no País, as empresas necessitam de estratégias de planejamento e de alternativas inovadoras para atrair e fidelizar clientes (KOTLER et al., 2006, p. 181).

A inovação consiste na adoção de medidas criativas por parte de gestores capazes de atribuir aos lugares aspectos característicos, únicos e inconfundíveis. A autenticidade tornou-se algo em voga e, sem sombra de dúvidas, as novas correntes de fluxo turístico buscam o diferencial nos destinos, seja o único, o curioso ou o lúdico. (MORAES, 1999, p. 16)

Destarte, o presente artigo busca analisar o mítico como produto turístico, versando sobre o mito do Lobisomem de Joanópolis/SP e, tendo como objeto de estudo o Botequim da Cachaça, também conhecido pelos populares como o Boteco do Lobisomem, situado na Estância Turística de Joanópolis.

Situa-se o leitor que o caso do Botequim da Cachaça surge com um elemento prático com o qual se permite entender de que modo os conceitos de autenticidade, empreendedorismo, diversificação de produtos e criatividade são elementos que podem potencializar a angariação de demanda turística no contexto real atual.

\section{METODOLOGIA}

Buscando entender o lugar como atrativo turístico, tendo como foco a apropriação de um mito folclórico para o comércio turístico, utilizou-se como metodologia de pesquisa uma pesquisa bibliográfica exploratória, em livros, revista e artigos científicos e, além disso, uma entrevista semiestruturada com os proprietários do Botequim da Cachaça, Wilson e Lurdes, no dia seis (06) de setembro de dois mil e quinze (2015).

A despeito da estruturação do roteiro da entrevista semiestruturada, entende-se que essa metodologia fora utilizada na intenção de obter um conjunto maior de respostas dos entrevistados, uma vez que por meio de uma "conversa" os entrevistados não se veem obrigados a fornecer respostas prontas. A entrevista semiestruturada versou sobre a origem da ideia do negócio, dificuldades, histórico de funcionamento, momentos positivos, a lenda do lobisomem e outros assuntos que auxiliaram no entendimento e na discussão da temática proposta neste trabalho. 
Além disso, o presente artigo dispõe de fotos que auxiliam no entendimento dos fatos abordados, bem como o espaço do Botequim da Cachaça, souvenirs e a caracterização do espaço.

\section{A CONCEPÇÃO DE PRODUTO TURÍSTICO}

A atividade turística se situa no terceiro setor da economia e não desenvolve produtos para consumo de clientes, ainda que muitos autores considerem o artesanato como um produto factível do turismo. O produto turístico, por sua vez, possui concepções diferenciadas dos produtos do primeiro e segundo setor econômico. Moraes (1999) define produto turístico como

[...] um conjunto de bens e serviços que objetivam satisfazer o cliente. É tangível (bens de consumo e industriais), pois se compõe de uma parte concreta (equipamentos hoteleiros e de restauração e meios de transportes), assim como intangível (prestação de serviços, um conjunto de ações que possibilita usufruir esses bens). (MORAES, 1999, p. 15)

Pela concepção de Moraes (1999) é possível entender a vertente tangível e intangível do produto turístico. Desse modo, quando menciona-se o caráter intangível considera-se a abstração um elemento característico do produto turístico, sendo que o consumidor não pode vê-lo antes de efetuar a compra, ou seja, não é possível realizar uma viagem antes de comprá-la. Isso pode ser melhor entendido por Atelijevic e Li, que afirmam:

[...] Ao contrário de outras indústrias, cujos produtos têm um uso ou valor de uso mais claramente definido (e isso pode ser visto ou sentido antes do ato de consumo), no turismo, a utilidade do produto é geralmente baseada na percepção e na curiosidade do turista [...]. (ATELIJEVIC; LI apud ATELJEVIC; PAGE; ALMEIDA, 2011, p. 6)

Rose (2002, p. 45) aborda em sua conceituação o produto turístico como algo "constituído pelo conjunto de bens e serviços colocados no mercado para satisfação das necessidades dos turistas. Em sua forma mais simples, trata-se do composto de atrativos naturais, culturais, estrutura turística, preço e comercialização [...]", quando define-se o produto turístico como um serviço deve-se considerar que os serviços não podem ser estocados e sua validade compete ao espaço temporal imediato, ou seja, não é possível voltar ao tempo para ocupar uma unidade habitacional (UH) que amanheceu desocupada.

Desse modo, é possível determinar que o produto turístico, bem como presente no setor de serviços, possui quatro características básicas, as quais duas já foram mencionadas: a "intangibilidade" e a "perecibilidade". Além dessas, Kotler (2011, p. 312) disserta em seu livro Principles of Marketing, acerca da existência de mais duas: a variability (inconstância) que pode ser entendida basicamente pelos diferentes tipos de atendimento que um mesmo lugar pode oferecer de acordo com a variabilidade do comportamento humano; e, por fim, a inseparability (inseparabilidade) aspecto que destaca que os serviços são gerados e consumidos ao mesmo tempo.

Komppula (2001), em sua indagação, traz outras características para o produto turístico, segundo ele “[...] o produto turístico, por si só, é dividido em dois níveis: a) o nível total, que se refere à experiência total dos turistas (desde a hora que sai de casa até a hora em que retorna), e b) o nível específico, que se refere a um produto específico oferecido por uma só empresa”. Nessa conjuntura, Komppula (2001) traz elementos significativos para a atratividade do produto turístico. Na primeira o turismo atua como um promotor de experiências, e na segunda como sendo uma empresa, uma parte condicionante em ofertar 
uma boa ou uma má experiência.

Destarte, enfatiza-se a empresa como um dos produtos do turismo responsável por ofertar experiências ao turismo. Contudo, na era globalizada de culturas plurais, essas empresas necessitam ter características diferenciadas, capazes de aguçar a curiosidade humana. Atelijevic e Li mencionam que (apud ATELJEVIC; PAGE; ALMEIDA, 2011, p. 6) “[...] compreender a curiosidade humana é, na verdade, uma precondição essencial para o entendimento do empreendedorismo turístico. Esse utiliza a manipulação da curiosidade humana para fins comerciais, e isso é fundamental para a habilidade empreendedora [...]".

Assim, o comportamento do consumidor no turismo visa a escolha de produtos diferenciados, lugares que possuam características próprias, que inspirem sonhos, ou seja, trabalhem com o lado lúdico humano, dado que "muitos exemplos provam que a curiosidade humana, certamente, é o pilar central de muitos produtos e serviços turísticos. O produto turístico pode ser quase tudo que provoque curiosidade humana, desde que seja nomeado, descrito, precificado e oferecido [...]" (ATELIJEVIC; LI apud ATELJEVIC; PAGE; ALMEIDA, 2011, p. 6).

Portanto, as empresas que oferecem produtos turísticos necessitam de um planejamento estratégico para que consigam exercer algum poder de atratividade ante a grande diversidade de concorrentes no mercado turístico. Assim, desponta o pensamento do lugar como atrativo, basicamente entendido como o estabelecimento comercial como elemento indutor de correntes turísticas.

\section{A ATRATIVIDADE TURÍSTICA}

Quando menciona-se o caráter atrativo da atividade turística suscitam-se inúmeros conceitos e divisões na academia. Assim, o produto turístico também possui diferentes formulações, divisões e interpretações. Ele pode ser entendido também como oferta turística, que, por sua vez, se divide em original e agregada, bem como os atrativos turísticos, recursos turísticos e os equipamentos e serviços turísticos.

Braga (2007, p. 79) menciona que atrativo turístico é “[...] um elemento que efetivamente recebe visitantes e tem estrutura para propiciar uma experiência turística. Nesse caso, o recurso foi adaptado para tornar-se atrativo [...]". O atrativo turístico diverge do recurso turístico, uma vez que os "recursos turísticos são os elementos de uma localização que tem potencialidade para tornar-se atrativo turístico; ou seja, constitui-se na matéria-prima do turismo [...]" (BRAGA, 2007, p. 79).

Desse modo, a concepção de equipamentos e serviços turísticos, por sua vez, pode ser compreendida nos seguintes termos:

Os equipamentos e serviços turísticos formam o conjunto de empreendimentos e negócios relacionados ao turismo,

direta ou indiretamente, tais como hospedagem, alimentação, entretenimento, agenciamento, trabalho de guias, locações de meios de transporte, locais para eventos e muitos outros. (BRAGA, 2007, p. 79)

Dias (2003, p. 209) menciona que os recursos e os atrativos turísticos "constituem um dos fatores determinantes para o desenvolvimento da atividade turística, e que de um modo geral motivam o indivíduo a viajar [...]". Observa-se, assim, que ambos são elementos indutores de turistas, contudo é possível aferir que os equipamentos e serviços turísticos também podem ter a função de atrair turistas, uma vez que é possível o espaço comercial absorver o caráter de atrativo turístico. 
Essa concepção pode ser embasada, sendo que "o atrativo turístico possui, via de regra, maior valor quanto mais acentuado for seu caráter diferencial. O turista procura sempre aquilo que é diferente de seu cotidiano. Assim, aquele atrativo único, sem outros semelhantes, possui maior valor para o turista" (ROSE, p. 47). Nesse sentido, se um estabelecimento comercial possui características singulares, seja pela sua decoração, insumos, temática ou hospitalidade, o espaço acaba por tornar-se um elemento chamariz para turistas.

Dessa maneira, faz-se necessário considerar que o caráter atrativo de uma localidade é subjetivo, assim como explana Kotler:

Pessoas diferentes podem ter imagens bastante diversas do mesmo lugar. Uma pessoa pode ver determinada cidade simplesmente como sua terra natal, enquanto outra pode vê-la como uma cidade dinâmica, uma selva urbana ou um excelente destino de fim de semana [...]. (KOTLER et al., 2006, p. 84)

Por meio dessa concepção reafirma-se o pensamento do local (estabelecimento comercial) como atrativo, sendo este capaz de induzir correntes turísticas, dado que o turista, conforme exposto anteriormente, busca viver novas experiências, as quais podem ser vivenciadas nos recursos e nos atrativos turísticos, ou, em especial, nos equipamentos e serviços turísticos.

Ao redor do mundo visualizam-se muitos estabelecimentos concebidos como atrações turísticas, assim como os Pub’s Ruínas de Budapeste/Hungria, a cervejaria Delirium em Bruxelas/Bélgica, a cervejaria Heineken em Amsterdã/Holanda, entre outros exemplos.

\section{O MITO NA ESTÂNCIA TURÍSTICA DE JOANÓPOLIS}

A Estância Turística de Joanópolis está situada nos conformes da Serra da Mantiqueira, e possui como municípios limítrofes Extrema/MG, Itapeva/MG e Piracaia/SP. O município faz parte da Mesorregião Macro Metropolitana Paulista e da Microrregião de Bragança Paulista (BRASIL, 2012).

Trata-se de um município de porte pequeno de população média de 11.768 habitantes (em 2010) e, segundo estimativas do Instituto Brasileiro de Geografia e Estatística (IBGE), 12.725 habitantes em 2015 (IBGE, 2015). Sua economia tem base na pecuária, produção agrícola, comércio e serviços, bem como na atividade turística.

A história do município tem origem nos desbravamentos dos bandeirantes, que dirigindo-se a Minas Gerais fazem menção à região em 1749. Contudo, o início da colonização dessas terras se desenvolveu por volta de 1878, ano que marca a fundação do bairro de São João do Curralinho, pertencente ao município de Santo Antônio da Cachoeira (atualmente conhecido como Piracaia/SP). A partir da criação do bairro e do início da construção do que viria a ser a futura cidade, e também com a expansão cafeeira, em poucos anos a localidade foi elevada a distrito e, posteriormente, à categoria de município em 1917, passando a nomear-se como Joanópolis, que significa cidade de João, em homenagem ao seu padroeiro São João Batista (NAKAGAWA, 2012).

Por conta de suas sinuosas ruas, arquitetura das casas, belezas paisagísticas, grande biodiversidade, aspecto histórico, patrimônio material e imaterial, no dia 23 de janeiro de 2001 o município foi elevado a Estância Turística. 
Ao longo dos anos a cidadezinha conquistou inúmeras expressões que a caracterizavam, como "a cidade que nasceu de uma festa" e "a capital do lobisomem". Segundo Mônica (2001, p. 31), essa intitulação pode ser entendida na linguagem folclórica como antonomásia, que compreende na "substituição do nome próprio por um comum ou por uma expressão que dê a entender o que se pretendia dizer".

A antonomásia "A capital do Lobisomem" faz referência ao mito do Lobisomem. Cabe ressaltar que, segundo Almeida (1965, p. 166), o mito pode ser entendido por "figuras e os acontecimentos de pura imaginação, que nunca tiveram correspondência histórica", ou seja, histórias que não possuem comprovação e, além disso, ultrapassam regiões, estados ou países.

A caracterização do município de Joanópolis como "capital do Lobisomem" surgiu em 1983 com uma estudante da Escola de Folclore de São Paulo, Maria do Rosário de Souza Tavares de Lima, pertencente a uma família tradicional de Joanópolis, que escreveu sobre o Lobisomem em livro publicado em 2004, intitulado "Lobisomem: Assombração e Realidade" (PAIVA JÚNIOR; GODOY, 2000, p. 74).

A pesquisa ganhou grande notoriedade na época, trazendo olhares para os mistérios de Joanópolis. Segundo relatos, esse "lado tão especial atraiu mais olhares curiosos. E ainda na década de 1980, Joanópolis foi apontada como a Capital Nacional do Lobisomem. O Jornal 'O Estado de S. Paulo’ sugeriu a Joanópolis esse título que na época recaiu sobre a cidade como bomba" (PAIVA JÚNIOR; GODOY, 2000, p. 76).

Depois de alguns anos da publicação da pesquisa os comentários sobre a terra do lobisomem diminuíram, mas Paiva Júnior e Godoy (2000, p. 78) ressaltam que "o lobisomem ressurgiu em Joanópolis em uma época, em um outro tempo. Mais de dez anos depois, em 1998, um comercial de televisão trouxe o lobisomem de volta". O comercial foi de uma rede de fast food, que tinha como tema o Lobisomem e foi gravado na própria cidade.

Após a veiculação do comercial, foi fundada em 22 de agosto de 1998 a Associação dos Criadores de Lobisomem - ACL, que tem como intuito disseminar e perpetuar a imagem de Joanópolis como "A Capital do Lobisomem”. Paiva Júnior e Godoy (2000) apresentam em seu livro “Lobisomem existe!”, por meio de uma série de entrevistas com joanopolenses, que:

Num estalo o mito rompeu fronteiras. Foi festejado no único clube de Joanópolis, ganhou coluna de jornal e um
programa de rádio na cidade vizinha, Piracaia. Em um dos programas de rádio, um ouvinte chegou a denunciar que
certa pessoa da cidade virava lobisomem. A audiência aumentava cada vez mais e o bicho cresceu na consideração
do povo. O lobisomem, criatura secular, se transformou em um ser multimídia. Tem até site na Internet! (PAIVA
JÚNIOR; GODOY, 2000, p. 81)

A partir disso é possível observar a utilização da imagem do lobisomem com finalidades comerciais, ou seja, utilização do mito como um chamariz para o comércio e indução de turistas. Essa atratividade se dá por meio de histórias, insumos, camisetas, canecas, artesanato e outros objetos que possam ser comercializados fazendo referência à temática. Essa concepção pode ser entendida por meio de Lima (2004), que disserta:

\footnotetext{
$\mathrm{Na}$ ação publicitária da cultura de mídia explora-se o impacto do mídia no consumidor em potencial. Determina marca de carro, talão de cheques, uísque, refrigerante, cosméticos, alimento, cigarro, calça de brim, material de limpeza ou qualquer outro produto, assumem feições de mito, com propalados efeitos mágicos, capazes de proporcionar uma vida melhor, alegria, saúde, juventude, poder, projeção social, destaque pessoal, felicidade. São os mitos modernos, da cultura mercantil, tão objetos de culto quanto todos os outros. (LIMA, 2004, p. 14)
} 
Portanto, a apropriação do mito do lobisomem, em especial, possuiu e possui inúmeras vertentes de utilização para usufruto turístico. Contudo, ressalta-se que o mito do lobisomem possui um lado obscuro, dados os hábitos e o fadário do próprio personagem e, assim, para desconstruir as características maléficas do personagem a Associação dos Criadores de Lobisomem - ACL desenvolveu uma imagem positiva do lobisomem. Em seu livro, Paiva Júnior e Godoy (2000, p. 90) realizam uma entrevista com o vicepresidente da ACL que exemplifica que "precisamos 'criar' um lobisomem bonzinho. Mudar um pouco essa cara de que lobisomem come crianças, rola em estrume de galinha. Vamos criar um lobisomem moderno, diferente".

Essa concepção também pode ser reafirmada por Valter Cassalho (CASSALHO, 2015), presidente da Associação dos Criadores de Lobisomem, que relata:

Dizem que, quem tem muita sorte nasce virado pra lua e Joanópolis parece ser uma dessas cidades em que a lua dá muita sorte, principalmente a lua cheia, pois é nela que o lobisomem costuma aparecer. Temido no passado, o lobisomem joanopolense passou por nova metamorfose, deixou de ser amaldiçoado para dar sorte, de mau passou a brejeiro e de temido passou a ser amigo. (CASSALHO, 2015)

E por meio dessa "metamorfose", conforme relatado pelo autor, a imagem do Lobisomem ganhou público, tornou-se atrativa e foi apropriada como uma temática indutora de turistas para estabelecimentos e, além disso, para o município como um todo. Giovane (2015, p. 8) observa que “[...] ao andar pelas ruas da pequena Joanópolis é possível ver vários desses lobisomens espalhados pelo comércio, um mais criativo do que o outro, que convidam os visitantes a tirar uma foto".

Cassalho (2015) conceitua que esse interesse pelo mito do Lobisomem pode ser entendido como o Turismo do Imaginário, ou seja, o lúdico como atrativo. Segundo o autor:

Costumo partir do pressuposto que os mitos sempre povoaram as mentes dos homens, desde os mais remotos tempos o homem viaja em busca de seu imaginário, em busca do encontro com o sobrenatural, com o sagrado, com as possíveis aventuras com o inesperado. Tornou-se um aventureiro, visitando locais que acreditava possuir energias diferentes, monstros, deuses e até mesmo passar por um portal mágico que o levasse a outros mundos. (CASSALHO, 2015)

Portanto, observa-se que o município de Joanópolis congregou inúmeros fatores que contribuíram para a agregação da imagem municipal como "A Capital do Lobisomem". Mas o caráter atrativo lúdico atribuído ao município não está intrínseco somente ao seu nome, mas também aos pontos comerciais que se tornam lugares atrativos por trabalharem com a temática do Lobisomem.

Em seu texto, Cassalho (2015) argumenta que:

Hoje em dia, o lobisomem pode ser considerado o carro-chefe na divulgação do turismo da cidade, aproveitando o folclore e mostrando as belezas naturais que o município encerra. No mês de agosto acontecia a Trilha do Lobisomem, ocasião em que dezenas de jeepeiros percorriam a madrugada joanopolense na esperança de ver o bicho. Além disso, as pessoas estão descobrindo os mistérios da lua cheia, ou seja, estão reatando com seu imaginário, buscando ouvir e relembrar as histórias de assombração e outros contos, pacientemente contados pelas pessoas mais antigas da família ou da comunidade. (CASSALHO, 2015)

A atratividade municipal, quando refere-se ao mito do Lobisomem, está atrelada aos estabelecimentos comerciais que se apropriaram do mito para o comércio, reforçando a própria localidade como um cenário possível para disseminação do mito e, em consequência, o status, ou seja, o reconhecimento do lugar como "A Capital do Lobisomem". 


\title{
LOBISOMEM O MITO
}

O Lobisomem é um personagem pertencente ao folclore brasileiro. Esse fato se deve ao ícone estar inserido no saber popular, que é passado de geração em geração. Horta $(2004$, p. 4) afirma que o fenômeno folclórico "é tradicional, seguindo sua trajetória de incorporações ao saber do povo, a tal ponto de ser considerado por esse mesmo povo essencial à sua própria realidade”.

Diferentemente da lenda, o Lobisomem é considerado um mito, isso porque, segundo Almeida (1965, p. 167), "a lenda é uma narrativa em torno de um fato real, com uma explicação ou interpretação de uma figura, uma realidade ou um acontecimento histórico, em torno da qual a fantasia cria uma série de coisas irreais e até mesmo inverossímeis". Por meio do conceito de Almeida (1965), é possível considerar que as histórias por trás do Lobisomem não possuem embasamento histórico, desse modo acabam por se enquadrar nas características de mito; o mito, em especial, é criado pelos povos para explicar manifestações que o ser humano não é capaz de comprovar por meio da ciência, gerando assim um conjunto simbólico. Além disso, outro fato que pode ser mencionado é que a lenda restringe-se à localidade, já o mito extrapola os limites geográficos e possui inúmeras concepções em diferentes partes do globo.

Assim, o mito do Lobisomem possui inúmeras origens e acepções em diversos países. Uns dos relatos mais antigos que se tem registro sobre o mito provém da Grécia, segundo Lima (2004):

\begin{abstract}
$\mathrm{Na}$ Grécia, o rei Licaon tentou matar Zeus. Em outra lenda, Licaon fez um sacrifício humano e a ira divina recaiu sobre ele. Ou Licaon serviu a Zeus carne humana. Ou ainda Licaon sacrificou ao deus o seu próprio filho. Em todas essas lendas, o final é o mesmo. O rei foi transformado para sempre em lobo, como castigo. Mas se não se alimentasse de carne humana por dez anos, recuperaria o aspecto de homem. (LIMA, 2014, p. 34)
\end{abstract}

Já em Roma o mito data do século I, que, segundo Lima (2004, p. 33), "na Roma de Nero, Tiro Petrônio Arbiter escreve o Satíricon. No capítulo LXII, Niceros, no banquete de Trimalcion, relata a estória do soldado que se transforma em lobo". Já na Romênia, a concepção do Lobisomem era disseminada por Heródoto que:

Acreditava que povos do leste da Europa, onde situa a Romênia, possuíam a faculdade de se transformar em lobo, durante alguns dias do ano. Retornavam depois à forma humana. Esses povos, denominados Neuros, durante o culto ao deus-lobo, atacavam traiçoeiramente pessoas desprevenidas, com fins de antropofagia e também bebiam sangue humano. (LIMA, 2004, p. 34)

Ao longo dos anos desenvolve-se também a concepção de Lobisomem feminina, segundo Cascudo (2012, p. 70): "na África a mulher se pode tornar hiena e pantera. Na China, loba. Na Armênia também, por penitência de pecado mortal [...]”. Desse modo, é possível observar parte das diversificações do mito em suas diferentes acepções em diferentes sociedades e fases históricas, cabendo ressaltar que o mito transforma-se de região para região e também no espaço temporal, ou seja, nos relatos orais passados de geração em geração.

A chegada do mito no Brasil remonta à época da colonização do País, uma vez que, com os colonizadores europeus, vieram suas histórias, conhecimentos e costumes (CORREIA, 2008, p. 11). Apesar de certa similaridade entre o mito no Brasil, é inexistente um consenso sobre a verdadeira história de transformação e vida do lobisomem. Contudo, a concepção que mais é abordada pela linguagem popular diz que o Lobisomem

[...] é o filho mais moço de uma série de sete homens. Para livrar-se do fadário deve, segundo alguns informantes, ser batizado pelo irmão mais velho e, segundo outros, pelo irmão do meio, isto é, o quarto. Mais tarde deverá ser padrinho de crisma do irmão que o batizou, para confirmar [...]. (LIMA, 2004, p. 23) 
Maria do Rosário de Souza Tavares de Lima aborda em seu livro "Lobisomem: Assombração e Realidade" que o mito “(...) nunca, porém, se situa no contexto religioso ou é objeto de veneração. É só assombração que pertence para causar mal ou dar aviso de qualquer coisa que precisa saber (...)” (LIMA, 2004, p. 17). Por meio de sua concepção é possível compreender que o mito não detém um apelo religioso, contudo os mitos também surgem como função de alerta, ou seja, leva as pessoas a crerem que se não seguirem determinadas regras existentes na sociedade podem se tornar figuras folclóricas. Isso pode ser compreendido pelo trecho:

O fadário pode também recair em qualquer menino ou rapaz, mesmo não sendo o sétimo filho. Uns dizem que é castigo ou penitência que Deus dá. Outros acham que isso acontece por artes do Diabo - porque foi tocado pelo inimigo. Homem que fica 10 anos sem se confessar e sem comungar ou sem por a mão na água benta, não se livra do fadário. Quem falta ao respeito para com os pais ou padrinhos pode também virar Lobisomem; se for mulher, vira bruxa. (LIMA, 2004, p. 23)

Assim, visualiza-se o apelo aos bons costumes existentes nas histórias inventadas, objetivando criar certa condição às ações do homem, pois, conforme mencionado, se ele não comungar ou por a mão na água benta em 10 anos ele vira Lobisomem, sendo que esses costumes elencados fazem parte de rituais religiosos. Destarte, pode-se observar que não há uma veneração religiosa ao elemento mítico, mas sim a utilização deste para advertir sobre a ausência ou descumprimento de alguns costumes.

O mito brasileiro conta que depois da transformação o lobisomem deve correr sete praças, ou seja, sete cidades e retornar no tempo máximo de uma hora antes de raiar o dia, geralmente por volta das três da manhã, ou antes do galo cantar. As histórias contam que o personagem deve retornar ao seu local de origem para desvirar e voltar para casa, e, se não conseguir voltar a tempo, ele aparecerá nu onde estiver (LIMA, 2004, p. 25).

O lado maligno do mito deve-se aos hábitos macabros do personagem, segundo Lima (2004):

O Lobisomem está sempre rondando onde há mulheres grávidas ou criancinhas, especialmente se ainda pagãs. Ataca a própria esposa na tentativa de rasgar-lhe o ventre e comer o filho esperado, pois no estado de encantamento não tem consciência dos seus atos. Aprecia filhotes de animais de todas as espécies, excremento e carniça. (LIMA, 2004, p. 26)

Com medo das potencialidades ou não do Lobisomem, alguns destinos tornaram-se indutores de turistas que almejam obter conhecimento do mito e desvendar seus mistérios, como relatado anteriormente. No Brasil, em especial no Sudeste, destaca-se a Estância Turística de Joanópolis.

\section{O MITO COMO PRODUTO TURÍSTICO}

Embasado nos conceitos expostos anteriormente, o presente trabalho realizou uma entrevista semiestruturada com os proprietários do Botequim da Cachaça, situado em Joanópolis/SP, sendo eles, Wilson Roberto Lopes (LOPES, 2015a) e Maria de Lurdes Lopes (LOPES, 2015b), no dia seis (06) de setembro de dois mil e quinze (2015).

O Botequim da Cachaça, mais conhecido pela comunidade autóctone como o Boteco do Lobisomem (Figura 1), vem usando há alguns anos a imagem do mito do Lobisomem como um artifício temático para atrair fluxos turísticos para o estabelecimento e, em especial, para o município. 


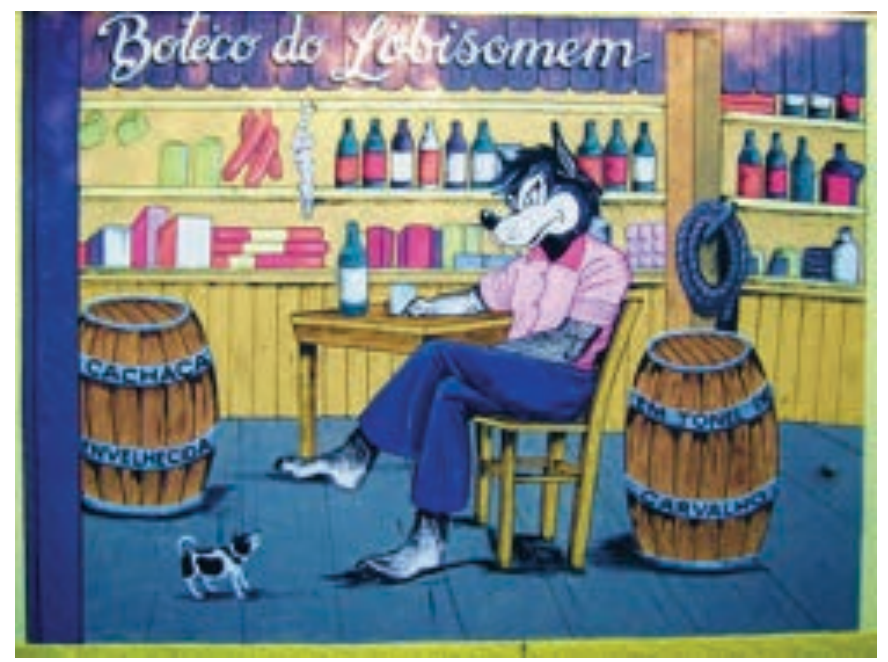

Figura 1 - Pintura na parede do Botequim

Foto: Wilson Lopes

O Botequim dispõe de rótulos, decoração, pintura, miniaturas e outros objetos que fazem referência ao Lobisomem (Figura 2), bem como explana Wilson sobre a cachaça mais conhecida, a Língua do Lobisomem:

É, a gente usou o nome na cachaça a Língua do Lobisomem, por quê? Porque ela deixa a língua azul, e dizem que o Lobisomem tem sangue azul, então. A cachaça do Lobisomem é uma cachaça azul, com gosto de curaçau, a língua do Lobisomem seria um gosto de groselha, mas é um nome que a gente colocou, a gente tinha uma porção do Lobisomem, que era uma carne seca feita com champignon e alguma coisa, que a gente parou até de fazer, mas era muito saborosa, e não sobrava para o Lobisomem [...]. (LOPES, 2015a)

Wilson relata que a história do Boteco do Lobisomem em Joanópolis começou há 10 anos, segundo ele: "na cachaçaria, eu já trabalho com mais de 35 anos, com cachaça, então meio sem querer começamos a trabalhar, e vendendo cachaça em bar, para bar, cachaça artesanal, a cachaçaria mesmo tem 10 anos". (LOPES, 2015a)

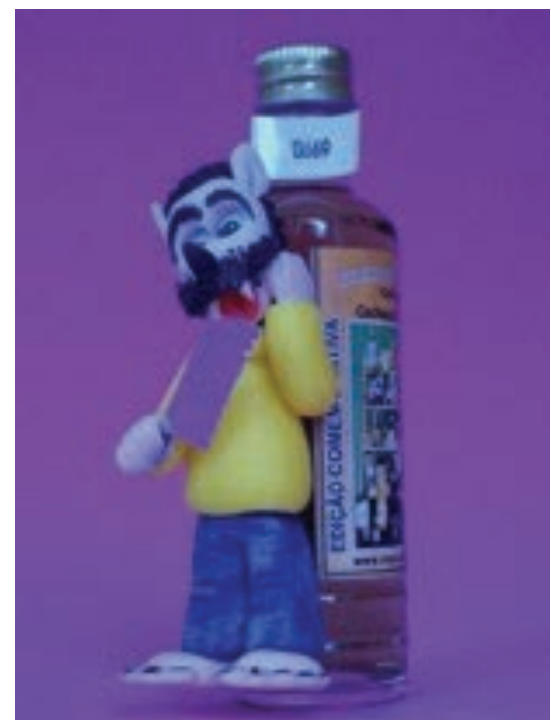

Figura 2 - Lobisomem de biscuit com cachaça artesanal.

Foto: Wilson Lopes 
Quando questionado aos proprietários de como surgiu a ideia de montar um botequim com a temática do Lobisomem, Lurdes (proprietária e esposa de Wilson) afirmou que:

[...] A gente queria fazer como, quem subia para ir para cachoeira ${ }^{1}$ dava de frente com aquela parede, primeiro eu queria, eu fui atrás de uma pessoa que me pintasse o Lobisomem, por que naquela época poucas pessoas, Joanópolis era contra esse negócio do Lobisomem, você sabe disso que um monte de gente, padre, e outras cositas. E aí eu queria que desenhasse um Lobisomem, fizesse uma janela, como se fosse uma porta, um balcãozinho [...]. (LOPES, 2015b)

Pelo relato de Lurdes é possível observar que na época o Lobisomem não era visto como um elemento positivo para a cidade, bem como afirma Cassalho (2015) “[...] antes todos corriam do Lobisomem, hoje as pessoas correm atrás dele [...]”.

Lurdes também comentou que o Boteco do Lobisomem foi o primeiro bar a ter um Lobisomem em tamanho real, pois, antes dele, só existia outro na Casa do Artesão de Joanópolis. Segundo ela:

[...] esse Lobisomem lá que fez o maior sucesso, todo mundo parava, porque de longe se você estivesse subindo, você imaginava que era uma pessoa que estava sentada, porque a gente colocava as roupas, a caráter de cada época, assim era festa junina, era ele vestido de festa junina, se era carnaval, enfeitava ele de carnaval, e ele fazia as poses ali, e aí foi. (LOPES, 2015b)

Salienta-se que este foi o primeiro espaço a ser ocupado pelo Botequim da Cachaça, atualmente eles possuem um espaço próprio, com bosque, cachaçaria, casa caipira, lago, parquinho para crianças e estacionamento, situado no Bairro do Bonifácio, estrada para a Cachoeira dos Pretos, Km 4,2.

Além da atratividade do ambiente, localizado no perímetro rural do município, e a atratividade dos objetos decorativos e insumos que versam a temática do Lobisomem (Figura 3), Wilson também argumenta que os turistas que visitam o espaço sentem-se instigados a saber o motivo do mito do Lobisomem em Joanópolis. Segundo ele:

[...] todos querem saber porque a cidade fala do lobisomem, o turista que chega aqui e fala porque tanto lobisomem, porque tanto desenho, porque tanto boneco, porque tanto lobisomem. E aí seria essa explicação né: Que não é história do lobisomem, aqui tem lobisomem mesmo, mas só tomar umas 100 pingas que eu tenho aqui, você já vê o lobisomem. (LOPES, 2015a)

A atração pelo mítico manifestada pelos turistas pode ser entendida por meio do pensamento de Lima (2004, p. 15) afirmando que "as características do sobrenatural, da existência de fantasmas, assombrações e vampiros, dos filmes exibidos revelam bem a particularidade mítica que atrai e seduz, o fascínio exercido pelos habitantes desse mundo encantado e fantástico". Assim, o emprego desses personagens que chamam atenção dos espectadores em estabelecimentos comerciais, pode, conforme observado, tornar-se um elemento de marketing a ser considerado, capaz de motivar fluxos turísticos.

1 Cachoeira dos Pretos, atrativo natural que mais movimenta fluxos turísticos na Estância Turística de Joanópolis (SOLHA, 2003, p. 88). 


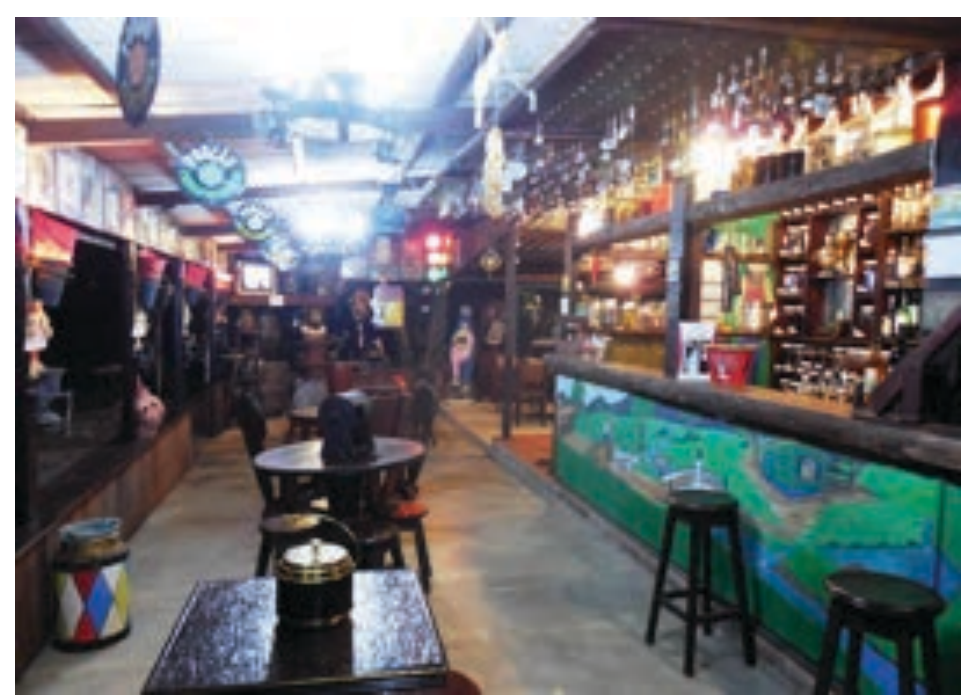

Figura 3 - Botequim da Cachaça (foto noturna).

Foto: Wilson Lopes

Wilson versando sobre a estratégia de marketing e a caracterização do município como a "Capital do Lobisomem", ou "Terra do Lobisomem" afirmou que:

[...] Joanópolis ficou mais conhecida com o lobisomem do que com a Cachoeira dos Pretos, que o marketing de Joanópolis na televisão era o lobisomem, depois quando vinha alguém aqui, fazer alguma coisa sobre o lobisomem que conhecia a cachoeira. Mas a Cachoeira acho que no marketing mesmo, para divulgação, foi mais o lobisomem. (LOPES, 2015a)

Dado o reconhecimento de Joanópolis como um local que personifica a figura do Lobisomem, muitos empresários começaram a investir no Lobisomem como comércio, assim como fez Lurdes e Wilson. Entretanto, Wilson pondera que com o "[...] lobisomem a gente criou até inimizade com as pessoas que mexiam com isso, que a gente entro em uma coisa que eles mexiam, tanto que a gente não podia expor na casa do artesão porque já tinha lá [...]”. (LOPES, 2015a)

Destarte, observa-se um fenômeno de apropriação particular de um mito que pertence ao folclore e, portanto, é um bem imaterial da sociedade. Assim, apesar das desavenças retratadas por Wilson, a Estância Turística de Joanópolis possui vários estabelecimentos comerciais que aderiram ao temário, decorando seus ambientes com Lobisomens em tamanho real. Os empresários buscaram, dessa forma, ressaltar no caráter visual de seus estabelecimentos a imagem mítica que representa e fortalece a representação do município enquanto destino turístico.

Dessa maneira é possível relacionar o mito do Lobisomem como um elemento da imagem da Estância Turística de Joanópolis, pois:

Definimos imagem de um lugar como um conjunto de atributos formado por crenças, ideias e impressões que as pessoas têm desse lugar. As imagens costumam representar a simplificação de inúmeras associações e fragmentos de informações e são o produto da mente tentando processar e enquadrar enormes quantidades de dados relacionados a um lugar (KOTLER et al., 2006, p. 182).

Portanto, assim como no Botequim da Cachaça, o Lobisomem apresenta-se como um elemento capaz de ser apropriado para caracterizar a demanda turística de um determinado lugar, caracterizando desde a motivação dos turistas ao tipo de turismo do imaginário que se desenvolve. 


\section{CONSIDERAÇÕES FINAIS}

A crise financeira da atualidade, determinante da concorrência entre destinos, da desvalorização da moeda nacional e dos novos gostos dos turistas, é um fator que necessita ser analisado na formatação de novos destinos turísticos e sobretudo na implantação de um novo estabelecimento comercial.

Destarte, tornou-se possível observar a potencialidade da localidade (estabelecimento comercial) em tornar-se um elemento que atrai fluxos consideráveis de turistas, uma vez que os turistas procuram satisfazer suas curiosidades e vivenciar novas experiências e lugares que detenham características singulares, únicas e criativas, transformados em indutores de turistas.

Desse modo, observaram-se, também, as inúmeras formas de utilização de um mito para fins comerciais, ou seja, o mito como produto turístico, capaz de ser formatado e, assim, utilizado como elemento diferencial, competitivo e criativo para atrair turistas de diversos nichos sociais.

No caso do Lobisomem da Estância Turística de Joanópolis, em especial considerando o Botequim da Cachaça, observa-se a transformação de um personagem imaterial, existente nas histórias dos antigos, em um elemento palpável e capaz de caracterizar uma região, desencadeando, assim, no desenvolvimento turístico desta.

Outro fator que deve ser salientado é que o uso do Lobisomem como atrativo turístico auxilia na disseminação e perpetuação do mito, bem como mantendo vivos os mitos e lendas do folclore brasileiro e impedindo assim o efeito acultural que se visualiza na atualidade.

Portanto, conclui-se a premência de empresas situadas na atividade turística em remodelar seu produto turístico para que este torne-se atrativo e seja capaz de competir com os inúmeros fatores externos e internos presentes no ambiente empresarial que são capazes de influenciar na captação de clientes.

\section{REFERÊNCIAS}

ALMEIDA, R. Manual da coletânea folclórica. Rio de Janeiro: Campanha de Defesa do Folclore Brasileiro, 1965.

ATELJEVIC, J.; LI, L. Empreendedorismo turístico: conceitos e ideias. In: ATELJEVIC, J.; PAGE, S.; ALMEIDA, M. V. de. Turismo e Empreendedorismo. Rio de Janeiro: Elsevier, 2011.

BRAGA, D. C. Planejamento turístico: teoria e prática. Rio de Janeiro: Elsevier, 2007.

BRASIL, C. Município de Joanópolis. Cidade Brasil. Disponível em: 〈http://www.cidade-brasil.com. br/municipio-joanopolis.htmlı. Acesso em: 29 nov. 2015.

CASCUDO, L. da C. Geografia dos mitos brasileiros. São Paulo: Global, 2012.

CASSALHO, V. O Lobisomem. Estância Turística de Joanópolis. Disponível em: 〈http://www.joanopolis. com.br/o-lobisomem.html. Acesso em: 29 nov. 2015.

CORREIA, A. de O. A.; SILVA, M. de O. “Acorda, vem ver a lua...”: uma análise cultural da lenda do Lobisomem. XIII Encontro de Iniciação Científica/IX Mostra de Pós-graduação. Unital: 2008. 
DIAS, R. Planejamento do turismo: política e desenvolvimento do turismo no Brasil. São Paulo: Atlas, 2003.

GIOVANE, L. Lobisomem, mito e comércio. Jornal 0 Registro: Sul de Minas e Região de Bragantina. Extrema/MG: 28 mar. de 2015. p. 8.

HORTA, C. F. de M. M. (Coord.). 0 grande livro do folclore. Belo Horizonte: Editora Leitura, 2004.

INSTITUTO BRASILEIRO DE GEOGRAFIA E ESTATíSTICA. São Paulo: Joanópolis. Disponível em: <http://www.cidades.ibge.gov.br/xtras/perfil.php?lang $=\&$ codmun $=352550 \&$ search=saopaulo|joanopolis|infograficos:-informacoes-completas>. Acesso em: 29 nov. 2015.

JOANÓPOLIS, E. T. de. Sobre Joanópolis. Estância Turística de Joanópolis. Disponível em: 〈http:// www.joanopolis.com.br/sobre-joanopolis.html>. Acesso em: 29 nov. 2015.

KOMPPULA, R. New-produce development in tourism companies - case studies on nature-based activity operators. In: The Nordic Tourism Research Symposium, 10, Oct. Process dungs: Vasa, 2001.

KOTLER, P. et al. Marketing de lugares: como conquistar crescimento de longo prazo na América Latina e no Caribe. São Paulo: Prentice Hall, 2006.

KOTLER, P. Principles of marketing. 14th ed. Philip Kotler and Gary Armstrong. Pearson Education, 236-242, 2011.

LIMA, M. do R. de S. T. de. Lobisomem: assombração e realidade. 2. ed. São Paulo: 2004.

LOPES, W. R. Entrevista de Wilson Lopes cedida a Leonardo Giovane Moreira Gonçalves. Joanópolis, 6 set. 2015 .

LOPES, M. de L. Entrevista de Maria de Lurdes cedida a Leonardo Giovane Moreira Gonçalves. Joanópolis, 6 set. $2015 \mathrm{~b}$.

MORAES, C. C. de A. Turismo: segmentação de mercado: um estudo introdutório. In: ANSARAH, M. G. dos R. (Org.). Turismo: segmentação de mercado. São Paulo: Futura: 1999.

NAKAGAWA, J. M. Sobre Joanópolis. Estância Turística de Joanópolis. Disponível em: 〈http://www. joanopolis.com.br/sobre-joanopolis.html.. Acesso em: 29 nov. 2016.

PAIVA JÚNIOR; GODOY, S. Lobisomem Existe! Campinas: 2000.

ROCHA, J. M. T. Arte/artesanato de Alagoas. Maceió: Secretaria de Educação e Cultura, (s/d).

ROSE, A. T. de. Turismo - planejamento e marketing. Barueri/SP: Manole, 2002.

SOLHA, K. T. (Org.). Plano diretor de desenvolvimento turístico de Joanópolis. Prefeitura Municipal de Joanópolis. Joanópolis: USP, 2003. 